\title{
Yield Gap Analysis, Economics, Adoption, and Horizontal Spread of Tomato (Lycopersicon esculentum Mill.) Cultivation through Front Line Demonstration in Eastern Uttar Pradesh, India
}

\author{
P.K. Misra*, S.N. Singh, Pardeep Kumar, M.K. Pandey
}

DOI: 10.18811/ijpen.v5i02.9

\begin{abstract}
The present study was undertaken to found the yield gap through FLDS on tomato crop. The Krishi Vigyan Kendra, Varanasi conducted Frontline demonstration on 10 farmers for each year since 2010-11, 2011-12 and 2012-13 in different locations of Varanasi district. Frontline demonstrations were conducted on tomato by the active participation of the farmers with the objective of improved technologies of tomato production potential. Use of hybrid variety, balanced use of fertilizer on the basis soil testing report and integrated pest and disease management etc are the main technologies to be tested in this demonstration. Tomato is a major vegetable crop of eastern Uttar Pradesh. But the productivity of tomato are very low in this district due to lack of knowledge and partial adoption of recommended package of practice by tomato cultivators. The data of study revealed to the cost of cultivation, production, productivity, gross return and net return were collected as per schedule and analyzed. The result of present study revealed that average highest yield in demonstration was recorded $643.83 \mathrm{q}^{-1} \mathrm{~h}^{-1}$ was obtained in demonstrated plot over control $\left(522.66 \mathrm{q} \mathrm{ha}^{-1}\right)$ with an additional yield of $121.17 \mathrm{q} \mathrm{ha}^{-1}$ and the increasing the average tomato productivity by 23.88 per cent. The extension gap and technology gap ranged between 119.50 to 122.50 and 93.50 to $119.50 \mathrm{q} \mathrm{ha}^{-1}$, respectively, with the technology index of $16.51 \%$ during the demonstration years. Besides this, the demonstrated plots gave higher gross return, net return with higher benefit cost ratio when compared to farmer's practice. In present study efforts were also made to study the impact of FLD on horizontal spread which was increased $269.38 \%$, if appropriate package and practices are followed.
\end{abstract}

Keywords: Adoption, B: C ratio, Extension gap, Frontline demonstration, Technology gap, Technology index, Tomato, Yield.

International Journal of Plant and Environment (2019)

\section{INTRODUCTION}

T omato [Lycopersicon esculentum (Mill.)] is a nutrient dense super food that offers benefits to a range of bodily systems. It nutritional contents supports healthful skin, weight loss and heart health. It contains key carotenoids such as lutein and lycopene. These can protect eye against light induced damage. Tomato is cultivated extensively for its edible fruits. Labeled as a vegetable for nutritional purposes, tomatoes are a good source of vitamin A and $\underline{C}$ and is refers to as poor man's orange. It adds variety of colours to the food. Tomato is a very good appetizer and its soup is said to be a good remedy for patients suffering from constipations. The fruits are commonly eaten raw in salads, served as a cooked vegetable, used as an ingredient of various prepared dishes, and pickled. Additionally, a large percentage of the world's tomato crop is used for processing; products include canned tomatoes, tomato juice, ketchup, puree, paste, and "sun-dried" tomatoes or dehydrated pulp. It is known as productive as well as protective food. Tomato is short duration crop and it is fitted in different cropping system of cereals, grain, pulse and oilseeds and gives higher yields hence is of high economic value.

Tomato is one of the most important vegetable crops grown throughout the world under field and greenhouse conditions (Kaloo, 1986). In India tomato is the third largest vegetable next to only potato and brijnal with the production of about $7.60 \mathrm{Mt}$ (National Horticulture Board, 2013). India ranks third in area and production after China and Japan. The major tomato growing countries are USA, Italy, Spain, Portugal and Turkey. The cultivated tomato was originated in the Peru-Ecuador-Bolivia is of the Andes (South America). The tomato is a warm season vegetable crop that is the sensitive to frost and is killed by freezing temperatures.
${ }^{1}$ Krishi Vigyan Kendra, Siddharthnagar, Uttar Pradesh, INDIA under N.D. University of Agriculture and Technology, Kumarganj, Ayodhya, Uttar Pradesh, INDIA

Corresponding author:P.K.Misra, KrishiVigyan Kendra, Siddharthnagar, Uttar Pradesh, INDIA under N.D. University of Agriculture and Technology, Kumarganj, Ayodhya, Uttar Pradesh, INDIA, E-mail: pkmisra2001@gmail. com, Mobile: +91-9415365405

How to cite this article: Misra, P.K., Singh, S.N., Kumar, P. and Pandey, M.K. (2019). Yield Gap Analysis, Economics, Adoption, and Horizontal Spread of Tomato (Lycopersicon esculentum Mill.) Cultivation through Front Line Demonstration in Eastern Uttar Pradesh, India. International Journal of Plant and Environment 5(2): 124-128.

Source of support: Nil

Conflict of interest: None

Submitted:09/10/2018 Accepted:30/04/2019 Published:30/04/2019

Previously tomatoes were grown only in season-wise, but the picture has been changed since last 10-12 years. Now day's tomatoes are grown round the year

Tomato is cultivated for freshly fruits. Due to its nature of being short duration and high yield crop, it is becoming an important crop from economic point of view; therefore the area under its cultivation is increasing day by day. The area, production and productivity of tomato in India were $90.70 \mathrm{Mha}, 18653 \mathrm{Mt}$ and $20.56 \mathrm{q} \mathrm{ha}^{-1}$ during 2012 (Anonymous, 2013). Tomato is an important vegetable crop of the Uttar Pradesh (UP) and influences the economic condition of farmers of eastern UP. The area, production and productivity of tomato during 2010 were $6.40 \mathrm{Mha}, 2520 \mathrm{Mt}$ and $39.51 \mathrm{q} \mathrm{ha}^{-1}$, respectively (National Horticulture Board, 2013). 
India contributes about 11.2 per cent to world tomato production with Andhara Pradesh is highest tomato producer followed by Madhya Pradesh with sharing percentage of 12.94 and 11.68 (Directorate of Economics and Statistics, 2012). Uttar Pradesh production is $831.16 \mathrm{M}$ ton with 4.25 percentage of total India production. Tomato is a major commercial vegetable crop in Varanasi district. Farmers of the district are facing problems due to climate change which has lead to drought-like situation, drying up of bore wells, scarcity of labour, etc. in summers. Besides this lack of knowledge on use of bio-control agents and other simple intercultural operations are predominant reasons in escalating the cost of production and reducing yield potential of tomato. Farmers are also affected by the fluctuations in market prices. These above constraints increases the risk of tomato cultivation and thereby keeping this in view Frontline demonstrations were conducted to reinforce the confidence of farmers in getting increased profitability with better productivity.

\section{Material and Methods}

The present study was carried out by Krishi Vigyan Kendra Varanasi, Narendra Dev University of Agriculture and Technology, Kumarganj, Faizabad for three consecutive years from 2010-11 to 2012-13 in the farmers field in different locations of Varanasi district through front line demonstration. Front Line Demonstration is one such powerful tool for transfer of technology which practically exhibits the strength of new technologies in increasing yield and profit. Total 25 demonstrations were conducted in 25 farmer's on 5.0 ha lands in three years. Each frontline demonstration was laid out on 0.2 ha area while adjacent 0.2 ha was considered as control for comparison (farmer's practice). The selection of farmers was done on basis of survey by KVK and special training was organized for selected farmers on tomato cultivation. The difference between the demonstration package and existing farmers practice are mentioned in Table 1.

For the demonstration plot all the recommended package of practices like the use of bio control agents (Trichoderma and
Pseudomonas) enriched FYM, recommended dose of fertilizers, mulching and integrated pest management practices use of quality seeds of improved variety etc. The traditional practices were taken as a control. Field days were also conducted in each cluster to show the results of front line demonstration to the farmers of the same village and neighboring villages. In general, soils of the area under study were sandy to sandy loam with medium to low fertility status and the average annual rainfall of this area is $998 \mathrm{~mm}$ and temperature varies from 15 to $45^{\circ} \mathrm{C}$ with average temperature $26.16^{\circ} \mathrm{C}$. The data of yield, pest management, production cost and returns were collected by KVK, scientists with frequent field visits during 2010-11 to 2012-13 from front line demonstration plots and farmers practice plot (control plot) and finally extension gap, technology gap, and technology index were calculated as given as formula suggested by Samui et al. (2000) and Dayanand et al. (2012) as given below:

Per cent increase in yield $=$ Demonstration yield - farmers practice yield X 100 /Farmers practice yield

Technology gap = Potential yield - Demonstration yield

Extension gap $=$ Demonstration yield - Yield under existing practice

Technology index $=$ Potential yield - Demonstration yield $X$ 100 /Potential yield

The data of adoption and horizontal spread of technologies were collected from the farmers with the interaction them. Data were subjected to suitable statistical methods. The following formulae were used to assess the impact on different parameters of tomato crop.

Impact of yield = Yield of demonstration plot - yield of control plot/Yield of control plot X 100

Impact on adoption (\% change) $=$ No. of adopters after demonstration - No. of adopters before demonstration /No. of adopters before demonstration $\mathrm{X} 100$

Impact on horizontal spread (\% change) $=$ After demonstration area (ha) - Before demonstration area (ha)

Table 1: Level of use and gap in adoption extent of tomato technologies in study area.

\begin{tabular}{|c|c|c|c|}
\hline Crop operations & Improved package of practices & Farmers practices & Gap \\
\hline Variety & Hybrid Saktiman/ Namdhari seeds Pvt. Ltd. & & \\
\hline Soil testing & Have done in all locations & Not in practice & Full gap \\
\hline Seed rate & $100 \mathrm{gm} \mathrm{ha}^{-1}$ & $200 \mathrm{gm} \mathrm{ha}^{-1}$ & Partial gap \\
\hline Seed priming & $\begin{array}{l}\text { Seed priming was performed for better germination. Seeds } \\
\text { were soaked during night for } 8-10 \text { hours with natural water, } \\
\text { drained out excess water and dried in shade before sowing. }\end{array}$ & Not in practice & Full gap \\
\hline Seed treatment & Seed was treated by carbendazim @ $1 \mathrm{gm} \mathrm{kg}^{-1}$ seeds & Not in practice & Full gap \\
\hline Transplanting method & $\begin{array}{l}\text { Transplanting in raised bed distance Row to Row } 120 \mathrm{~cm} \& \text { Plant } \\
\text { to Plant } 90 \mathrm{~cm}\end{array}$ & $\begin{array}{l}\text { Flat bed transplanting } \\
\text { Row to Row } 60 \mathrm{~cm} \& \\
\text { Plant to Plant } 30 \mathrm{~cm}\end{array}$ & Partial gap \\
\hline Nursery time & September & Last week of September & Partial gap \\
\hline Transplanting time & October & November & Partial gap \\
\hline Fertilizer dose & Fertilizer@150 Kg N, $115 \mathrm{Kg} \mathrm{P}_{2} \mathrm{O}_{5}$ and $150 \mathrm{Kg} \mathrm{K}_{2} \mathrm{O} \mathrm{ha}^{-1}$ & $\begin{array}{l}\text { Without } \\
\text { recommendation }\end{array}$ & Partial gap \\
\hline Weed dose & $\begin{array}{l}\text { Pendimethalin @ } 1.0 \mathrm{~kg} \mathrm{ha}^{-1} \text { was applied immediately after } \\
\text { transplanting. }\end{array}$ & $\begin{array}{l}\text { Hand weeding/ rarely } \\
\text { used }\end{array}$ & Partial gap \\
\hline Multiplex nutrient spry & $\begin{array}{l}\text { @ } 2.5 \mathrm{gm} \mathrm{L}^{-1} \text { water and spray on both surfaces of leaves. First } \\
\text { spray just before flowering, second spray during flowering or } 25 \\
\text { days after first spray and third spray when fruits are bean size. }\end{array}$ & No application & Full gap \\
\hline Plant protection Measures & $\begin{array}{l}\text { Need based in case of severe infestations of TLCV imidaclroprid } \\
17.8 \% \text { SL. or dimethoate } 30 \mathrm{EC} @ 2 \mathrm{ml} \mathrm{L}^{-1} \text { and other systematic } \\
\text { chemicals }\end{array}$ & $\begin{array}{l}\text { Use chemicals with } \\
\text { recommendations }\end{array}$ & Partial gap \\
\hline
\end{tabular}




\section{Results and Discussion}

\section{Yield}

The perusal of data indicate that due to front line demonstration on tomato yield ranged from 630.50 to $656.50 \mathrm{q} \mathrm{ha}^{-1}$ in demonstration plots and from 511.00 to $535.00 \mathrm{q} \mathrm{ha}^{-1}$ in farmer's practice plot in three years of demonstration (Table 2). And average yield of 643.83 $\mathrm{q} \mathrm{ha}^{-1}$ was obtained under demonstration plots as compared to $522.66 \mathrm{q} \mathrm{ha}^{-1}$ in farmers practice plots in same years. This results clearly indicated that the higher average yield in demonstration plots over the years compare to farmers practice due to knowledge and adoption of full package of practices i.e. use of bio fertilizer enriched FYM, recommended dose of fertilizers, preparation of raised beds, mulching, pheromone traps and timely application of plant protection chemicals. The average yield of tomato is increased by 23.18 per cent. The yield of tomato could be increased over the yield obtained under farmers practices (lack of knowledge on use of bio fertilizers, no use of the balanced dose of fertilizer, no IPM practices) of tomato cultivation. The above findings are in similarity with the findings of Singh et al. (2011), Ashrafuzzaman et al. (2011) and Summers and Stapletion (2000). Similarly yield enhancement in different crops in frontline demonstrations were documented by Hiremath et al. (2007), Mishra et al. (2009), Kumar et al. (2010), Surywanshi and Prakash (1993), Dhaka et al. (2010) and Nagouajio et al. (2008).

The increment in yield ranged between 22.71 to 23.46 per cent. The per cent increase in yield over farmers practice was highest (23.46) during 2011-12. However variations in the yield of tomato in different years might be due to the variations in soil moisture availability, rainfall, and change in the location of demonstrations every year.

\section{Extension gap}

Extension gap of $119.50,122.50$ and $121.50 \mathrm{q} \mathrm{ha}^{-1}$ was observed during 2010-11, 2011-12 and 2012-13 respectively. On an average extension gap under three year FLD programme was $127.16 \mathrm{q} \mathrm{ha}^{-1}$. This emphasized the need to educate the farmers through various techniques for the adoption of improved agricultural production technologies to reverse this trend of wide extension gap. More and more use of latest production technologies with high yielding variety will subsequently change this alarming trend of galloping extension gap.

\section{Technology gap}

The technology gap, the differences between potential yield and yield of demonstration plots was $119.50,105.50$ and $93.50 \mathrm{q} \mathrm{ha}^{-1}$ during 2010-11, 2011-12 and 2012-13 respectively. On an average technology gap under three year FLD programme was $106.00 \mathrm{q} \mathrm{ha}^{-1}$. This may be due to the soil fertility, managerial skills of individual farmer's and climatic condition of the area. Hence, location specific recommendations are necessary to bridge these gaps. These findings are similar to Singh et al. (2011).

\section{Technology index}

The technology index shows the feasibility of the demonstrated technology at the farmer's field. The technology index varied from 14.24 to 18.95 (Table 2). On an average technology index of 16.51 per cent was observed during the three years of FLD programme, which shows the effectiveness of technical interventions. This accelerates the adoption of demonstrated technical interventions to increase the yield performance of tomato.

\section{Economic returns}

In order to found the economic feasibility of the demonstration technologies over and above the control, some economic indicators like cost of cultivation, net return and $\mathrm{B}: \mathrm{C}$ ratio was worked out. The economic viability of improved demonstrated technology over farmers practice was calculated depending on prevailing price of inputs and outputs cost and represented in the term of B:C ratio (Table 3). It was found that the cost of production of tomato under demonstration varied from Rs. 56,900/- to Rs. 62,500/- per ha with an average of Rs. 59,666/- as against Rs. 51,300/- to Rs. 56,500/- with an average Rs. 53,733/- under control. The additional cost increased in demonstration was mainly due to more cost involved in balanced fertilizer, procurement of improved hybrid seed and IPM practices.

The cultivation of tomato under improved technologies gave higher net return of Rs. 1,45,600/-, Rs. 1,58,300/- and Rs. 1,63,500/per ha in the year 2010-11, 2011-12 and 2012-13 respectively with an average net return of Rs. 1,55,800/- per ha which was lower Rs. $1,12,766.67$ in farmer's practices. The benefit cost ratio of tomato ranged from 2.61 to 2.65 in demonstration plots and from 2.06 to

Table 2: Productivity, technology gap, technology index and extension gap in tomato under FLD.

\begin{tabular}{|c|c|c|c|c|c|c|c|c|c|}
\hline & & & Yield ( $q$ ha & & & $\%$ & Extension & Technology & \\
\hline Year & (ha) & farmers & Potential & Demonstration & Control & in yield & $\left(q h a^{-1}\right)$ & $\left(q h a^{-1}\right)$ & index (\%) \\
\hline 2010-11 & 1.0 & 05 & 750 & 630.50 & 511.00 & 23.38 & 119.50 & 119.50 & 18.95 \\
\hline 2011-12 & 2.0 & 10 & 750 & 644.50 & 522.0 & 23.46 & 122.50 & 105.50 & 16.36 \\
\hline $2012-13$ & 2.0 & 10 & 750 & 656.50 & 535.0 & 22.71 & 121.50 & 93.50 & 14.24 \\
\hline Average & - & - & 750 & 643.83 & 522.66 & 23.18 & 121.16 & 106.00 & 16.51 \\
\hline
\end{tabular}

Control $^{*}=$ Farmers practice use as control

Table 3: Comparative C:B analysis of tomato under FLD and farmers practice.

\begin{tabular}{|c|c|c|c|c|c|c|c|c|}
\hline \multirow[b]{2}{*}{ Year } & \multicolumn{2}{|c|}{ Cost of cultivation } & \multicolumn{2}{|l|}{$\begin{array}{l}\text { Gross return } \\
\text { (Rs. per ha) }\end{array}$} & \multicolumn{2}{|c|}{$\begin{array}{l}\text { Net returns } \\
\text { (Rs.perha) }\end{array}$} & \multicolumn{2}{|c|}{ B:C Ratio } \\
\hline & Demo. & Control* & Demo. & Control* $^{*}$ & Demo. & Control* & Demo. & Control* \\
\hline 2010-11 & 56900 & 51300 & 202500 & 159000 & 145600 & 107700 & 2.55 & 2.09 \\
\hline 2011-12 & 59600 & 53400 & 217900 & 167500 & 158300 & 114100 & 2.65 & 2.13 \\
\hline $2012-13$ & 62500 & 56500 & 226000 & 173000 & 163500 & 116500 & 2.61 & 2.06 \\
\hline Average & 59666.67 & 53733.33 & 215465.66 & 166500 & 155800 & 112766.67 & 2.60 & 2.09 \\
\hline
\end{tabular}

Control $^{*}=$ Farmers practice use as control 
Yield Gap Analysis, Economics, Adoption, and Horizontal Spread of Tomato (Lycopersicon esculentum Mill.)

Table 4: Impact of Front Line Demonstration (FLDs) on adoption of tomato production technology.

\begin{tabular}{|c|c|c|c|c|}
\hline \multirow[b]{2}{*}{ Technology } & \multicolumn{2}{|l|}{ Numbers of adopters } & \multirow{2}{*}{$\begin{array}{l}\text { Change in no. of } \\
\text { adopter }\end{array}$} & \multirow{2}{*}{$\begin{array}{l}\text { Impact (\% } \\
\text { change) }\end{array}$} \\
\hline & Before demonstration & After demonstration & & \\
\hline Land preparation and FYM applications & 16 & 35 & 19 & 118.75 \\
\hline Recommended hybrid & 16 & 33 & 17 & 106.25 \\
\hline Seed rate & 03 & 27 & 24 & 800 \\
\hline Transplanting in raised bed & 14 & 30 & 16 & 114.28 \\
\hline Balance fertilizer application & 07 & 29 & 21 & 314.28 \\
\hline Weed management & 15 & 29 & 14 & 93.33 \\
\hline Spacing \& plant populations & 08 & 23 & 15 & 187.50 \\
\hline Foliar nutrition & 05 & 17 & 12 & 240 \\
\hline Recommended insect pest management & 04 & 26 & 22 & 550 \\
\hline Overall impact & & & & 269.38 \\
\hline
\end{tabular}

Table 5: Impact of Front Line Demonstration (FLDs) on horizontal spread of tomato hybrid.

\begin{tabular}{llllll}
\hline \multirow{2}{*}{ Variety } & \multicolumn{2}{l}{ Area (ha) } & & & \\
\cline { 2 - 3 } & Before demonstration & After demonstration & & Change in area (ha) & Impact (\% change) \\
\hline Saktiman hybrid tomato & 5.50 & 28.0 & 22.50 & 409.09 \\
\hline
\end{tabular}

2.13 in farmer's practice plots during three years of demonstration with an average of 2.60 in demonstration and 2.09 under farmer's practices. This may be due to higher yield obtained and lower cost of cultivation under improved technologies compared to local check (farmers practice). This finding is similar with the findings of Singh et al. (2011) and Schonbeck (1999). Similar findings are also reported by Chapke (2012) in case of jute.

The $\mathrm{B}: \mathrm{C}$ ratio was recorded to be higher under demonstration against control during all the years of study. Scientific method of tomato cultivation can reduce the technology gap to a considerable extent, thus leading to increased productivity of tomato in district which in term will improve the economic condition of the growers. Moreover, extension agencies in the district need to provide proper technical support to the farmers through different educational and extension methods to reduce the extension gap for better tomato production in the eastern Uttar Pradesh.

The result of improved technology intervention brought out that adoption of recommended hybrid of tomato by farmers before demonstration was negligible, which increased by 106.25 $\%$ after demonstration. Transplanting in raised bed technique was increased by $114.28 \%$ due to intervention through FLD. The overall adoption level of hybrid tomato production technology was increased by about 269.38 percent due to FLD conducted by KVK, Varanasi (Table 4).

In present study efforts were made to study the impact of FLD on horizontal spread of tomato hybrid. Data in Table 5 showed that FLD organized on tomato crop helped to increase area under recommended hybrid. There was significant increase area under horizontally from 5.50 to 28.0 ha under hybrid tomato.

\section{Conclusion}

The FLD produced a significant positive result and provided an opportunity to demonstrate the productivity potential and profitability of the latest technology (intervention) under real farming situation. Therefore the study concludes that FLDs conducted by KVK, Varanasi made significant impact on horizontal spread of this technology. Therefore, target oriented training programme on improved vegetable production technology along with multiple demonstration is required to enhance the level of knowledge and skills of growers which help in adoption of technology. This could circumvent some of the constraints in the existing transfer of technology system in the Varanasi district of Uttar Pradesh. The productivity gain under FLD over existing practices of tomato cultivation has created greater awareness and motivated other farmers to adopt the demonstrated technologies for tomato production in the district which helps to enhance the vegetable production consumption nutritional security and overall livelihood security of the districts of eastern Uttar Pradesh.

\section{References}

Anonymous 2013. Indian Horticulture Database 2012. National Horticulture Board, Ministry of Agriculture of India, pp. 4.

Ashrafuzzaman, M., Abdul Ismail, M.R. and Sahidullah, S.M. 2011. Effect of plastic mulch on growth and yield of chilli (Capsicum annuum L.). Brazilian Archives of Biology and Technology 54(2):32-330.

Chapke, R.R. 2012. Impact of frontline demonstration on Jute (Corchorus olitorious). Journal of Huan Ecology 38(1):37-41.

Dayanand, V.R.K. and Mehta, S.M. 2012. Boosting mustard production through front line demonstrations. Indian Research Journal of Extension Education 12(3):121-123.

Dhaka, B.L., Meena, B.S. and Suwalka, R.L. 2010. Popularization of improved maize production technology through front line demonstration in south-eastern Rajasthan. The Journal of Agricultural Science 1(1):39-42.

Directorate of Economics Statistics 2012. Department of Agriculture Cooperation and Farmers Welfare, Ministry of Agriculture and Farmers Welfare, Govt. of India.

Hiremath, S.M., Nagaraju, M.V. and Shasidhar, K.K. 2007. Impact of frontline demonstration on onion productivity in farmer's field. Paper presented In: National Seminar on Appropriate Extension Start Management of Rural Resource, University of Agriculture, Dharwad, December 18-20, pp. 100.

Kaloo, 1986. Tomato, Allied Publication Pvt. Ltd., New Delhi, India.

Kumar, A., Kumar, R., Yadav, V.P.S. and Kumar, R. 2010. Impact assessment of frontline demonstration of Bajara in Haryana state. Indian Research Journal of Extension Education 10(1):105-108.

Mishra, D.K., Paliwal, D.K., Tailer, R.S. and Deshwal, A.K. 2009. Impact of frontline demonstration on yield enhancement of potato. Indian Research Journal of Extension Education 9(3):26-28.

Nagouajio, M, Auras, R., Fernandez, R.T., Rubiono, M., Counts, J.W. and Kijchavengkul, T. 2008. Field performance of aliphatic-aromatic copolyster biodegradable mulch films in a fresh market tomato production system. HortTechnology 18(4):605-610.

National Horticulture Board 2013. Indian Horticulture Database, National Horticulture Board, Ministry of Agriculture, New Delhi, Govt. of India, pp. 14. 
Samui, S.K., Mitra, S., Roy, D.K., Mandel, A.K. and Saha, D. 2000. Evaluation of front line demonstration on groundnut. Journal of Indian Society of Agricultural Research 18(2):180-183.

Schonbeck, M.W. 1999. Weed suppression and labor costs associated with organic, plastic and paper mulches in small scale-scale vegetable production. Journal of Sustainable Agriculture 13:13-33.

Singh, R., Soni, R.L., Singh, V. and Bugalia, H.L. 2011. Dissemination of improved production technologies of solanaceae vegetables in
Banswara district of Rajasthan trough frontline demonstration. Rajasthan Society of Extension Education 19:97-100.

Summers, C.G. and Stapletion, J.J. 2000. Use of UV reflective mulch to delay the colonization and reduced the severity of Bemisia argentifolii (Homoptera: Aleyrodidae) infestations in cucurbits. Crop Protection 21:921-928.

Suryawanshi, S.D. and Prakash, M. 1993. Impact of viable technology of promoting oil seeds in Maharastra. Indian Journal of Agricultural Economics 48:102-106. 